\title{
Koedoe: African Protected Area Conservation and Science - A retrospection: 1958 to 2018
}

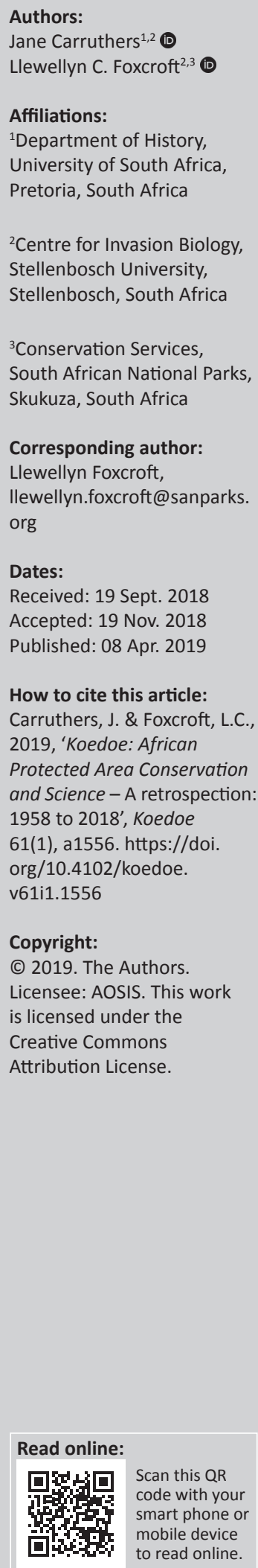

In 2018, Koedoe celebrated an unbroken publication record of 60 years. From uncertain beginnings in 1958, it is now a mature and important internationally recognised scientific journal focussing on conservation and science in national parks in South Africa and beyond into the African continent. After an overview of the emergence of national parks in the 20th century, this retrospective essay reflects on Koedoe's long and significant contribution to the field of national parks research and management. We identify and make easily available some of the seminal and influential articles that have appeared in the journal over this long time span. Principally relating to matters in national parks in South Africa, these articles (some coming from special issues of Koedoe) have been chosen for their variety as well as for the broader perspectives they open into the longer trajectory of national park conservation and management. Articles illustrate the evolution of paradigms from protectionist and species centric, to ecosystem focus, to complex socio-ecological systems and adaptive management. Conservationists, scientists and managers alike will benefit from an understanding of the transformations in their field over six decades together with appreciating the importance and usefulness of unpacking the intellectual journey of national park science in order to contextualise and enrich - even encourage and direct - present and future research.

Conservation implications: The articles included in this essay produced important information that informed and guided later research. Introducing these contributions to a fresh audience we hope will also tempt readers to consult other back issues of this journal, which will benefit conservation by providing an understanding of the long-term transformations in the field.

Keywords: biodiversity conservation; conservation journals; conservation science; ecology; environmental history; environmental science; South African National Parks.

\section{Introduction}

An anniversary is conventionally an occasion on which to celebrate, but it is also a time for reflection and for taking stock. The 60th anniversary of the publication record of the journal Koedoe: African Protected Area Conservation and Science is no exception. After six decades, Koedoe is a mature and important journal. For this commemorative retrospective issue we have decided to republish a number of papers on seminal work from the distant and more recent past that give a small taste of the contribution that Koedoe has made to the literature over 60 years. We also hope that this will tempt readers to turn to other articles in order to follow long-term threads in their own disciplines - as well as others - so as to appreciate how patterns have emerged and paradigms and priorities have changed. All too often science in the past is forgotten, or ignored, while some of the key work that has laid the foundation for future scientific endeavours lies in the rich knowledge accumulated over many decades.

The 1950s were important in the history of national parks worldwide (Carruthers 2017), and the remarkable longevity of Koedoe is a tribute to the enthusiasm of biologists during that decade in South Africa. In 1958, it was a novelty - indeed a very bold step - to publish any research conducted in a national parks organisation, and it is greatly to the credit of South African National Parks (SANParks) that support for Koedoe has never wavered.

National parks have a pedigree dating back to the 19th and early 20th centuries. However, it was only after World War II that, together with a rash of other institutions designed to herald a new era, the International Union for the Protection of Nature (IUPN) was founded at a meeting on 05 October 1948 at Fontainebleau, France, under the auspices of UNESCO (IUPN 1948). No delegate from southern Africa was present at that event, but before long there was strong engagement from the subcontinent. Throughout the 1950s and, indeed, beyond and into the present, South Africans - some affiliated to the National Parks Board (NPB), renamed SANParks 
in 1996 - played a role in shaping many of the International Union for the Conservation of Nature and Natural Resources' (IUCN) initiatives and policies as they carved a reputation for national park science at home.

In 1958 at the 6th General Assembly in Athens, the International Union for the Conservation of Nature and Natural Resources (IUCN, to which the IUPN changed its name in 1956; IUCN 1956) established a Provisional Commission on National Parks (Resolution 247), planned regular world congresses and decided to compile a list of the world's national parks. Interestingly, however, there was then no mention of defining a national park or any other protected area, although this, together with other bureaucratic steps, was to come in time. A number of South Africans at the Athens meeting participated in a variety of committees; among them were Rocco Knobel, Director of the NPB, who was elected to the Executive Board, and his colleague, R.J. Labuschagne. Representatives of the Transvaal and Natal conservation authorities were also active. The minutes record discussion on the importance of scientific, especially ecological, research in matters relating to conservation (IUCN 1960).

Within Africa, in 1953, the Bukavu conference of the IUPN had prioritised the protection of the fauna and flora of the continent. Importantly too, glimpses of the emerging disciplines of conservation science and, indeed the explosions of the environmental era, were increasingly visible in the 1950s. This was evident in South Africa, for example, with the introduction of various environmental or nature and wildlife conservation-oriented courses at universities, the establishment of the Percy Fitzpatrick Institute of African Ornithology (1959) and the Zoological Society of Southern Africa (1958). South African National Parks were in the vanguard of these developments with the establishment of the Biology Section of the Kruger National Park (KNP) in 1951. After a bruising internal commission of enquiry in 1952, and the consequent professionalisation of the NPB, stable management was critical to future scientific endeavour (Carruthers 2017).

It was into this wider scientific and organisational environment that the first issue of Koedoe appeared as an annual journal. Koedoe, which is the Afrikaans name for Tragelaphus strepsiceros, 'kudu' in English, had become the emblem of the NPB in 1955. There was an English subtitle the journal was bilingual - Journal for Scientific Research in the National Parks of the Union of South Africa (in Afrikaans, Tydskrif vir Wetenskaplike Navorsing in die Nasionale Parke van die Unie van Suid-Afrika). It is a matter of regret that there was no initial foreword or editor's message to explain exactly what Koedoe aimed to accomplish, and who the intended readership might be. National Parks Board liaison officer N.J. van der Merwe noted in 1962 that Koedoe was useful for exchanges and that the library in Skukuza had, by this means, received 92 scientific journals, 28 semi-scientific journals and 27 annual reports. This meant significant scientific material was available for research staff to use, thanks to the regular publication of Koedoe. A network had been established.
The first issue of Koedoe was impressive, with articles about an expedition to the Lowveld from Mozambique in 1725, a list of mammals of the Mountain Zebra National Park, a mosquito survey and fire research in the KNP, hyena observations and seven articles on the animals of the Kalahari Gemsbok National Park (KGNP). Five contributions were in Afrikaans and eight in English. Only two, however, were by research staff in the employ of the NPB: A.M. Brynard (on conditions in the KGNP) and H.P. van der Schijff (fire research in the KNP). At the time, there were five national parks under the banner of the NPB: Kruger, Bontebok, Addo Elephant, Kalahari Gemsbok and Mountain Zebra, and the staff was very small; since then, the number of parks has grown to 19 and staff numbers have burgeoned.

With the passing years Koedoe has become a highly respected, peer reviewed, open access academic journal of a kind that could never have been foreseen in the 1950s (Foxcroft 2008; Foxcroft \& Herbst 2017). The credibility of Koedoe was further strengthened in 2013 when Koedoe received its first impact factor of 1.48, fluctuating to the current rating of 0.9 (Clavariate Analytics Journal Citation Reports). Moreover, although Koedoe has always welcomed contributions beyond national parks, its current subtitle African Protected Area Conservation and Science reflects its formally changed focus to cover the entire continent and all kinds of protected areas, not only national parks and not only about South Africa.

Not surprisingly, the content of Koedoe has varied enormously in scope and quality since 1958: there have been substantial articles and extensive lists but also, often, short pieces of a page or two about an unusual sighting or a new record. Naturally, as a largely in-house journal until recently, the interest, importance, topicality or institutional relevance of an article has sometimes exceeded the value of the research it communicated. In addition, although research articles were mostly reviewed, professional, rigorous, peer review was not the requisite that it is now. Nonetheless, one must emphasise the novelty and importance of such an interdisciplinary research journal, as well as its pioneering role in providing a platform for disseminating the knowledge generated in or about national parks in our country. As a record of a long period of locality-based research, Koedoe is an incomparably rich resource, and it records the names of the most eminent scientists in South African national park science, both within SANParks and outside it.

The short selection of just more than a dozen past articles included in this celebratory issue is, naturally, subjective, perhaps idiosyncratic. It was no easy task to decide what to include from the more than 1250 articles - for Koedoe is brimfull of interesting contributions, all of which have a point to make. However, we have focused on some of those that, in our view, capture changes in the emphasis, or type, of scientific research conducted in South Africa's national parks and the philosophy that underpinned research and management (see Figure 1). We have also sought out different disciplines and tried to convey a little of the variety of national parks that have been highlighted in Koedoe since 1958. 


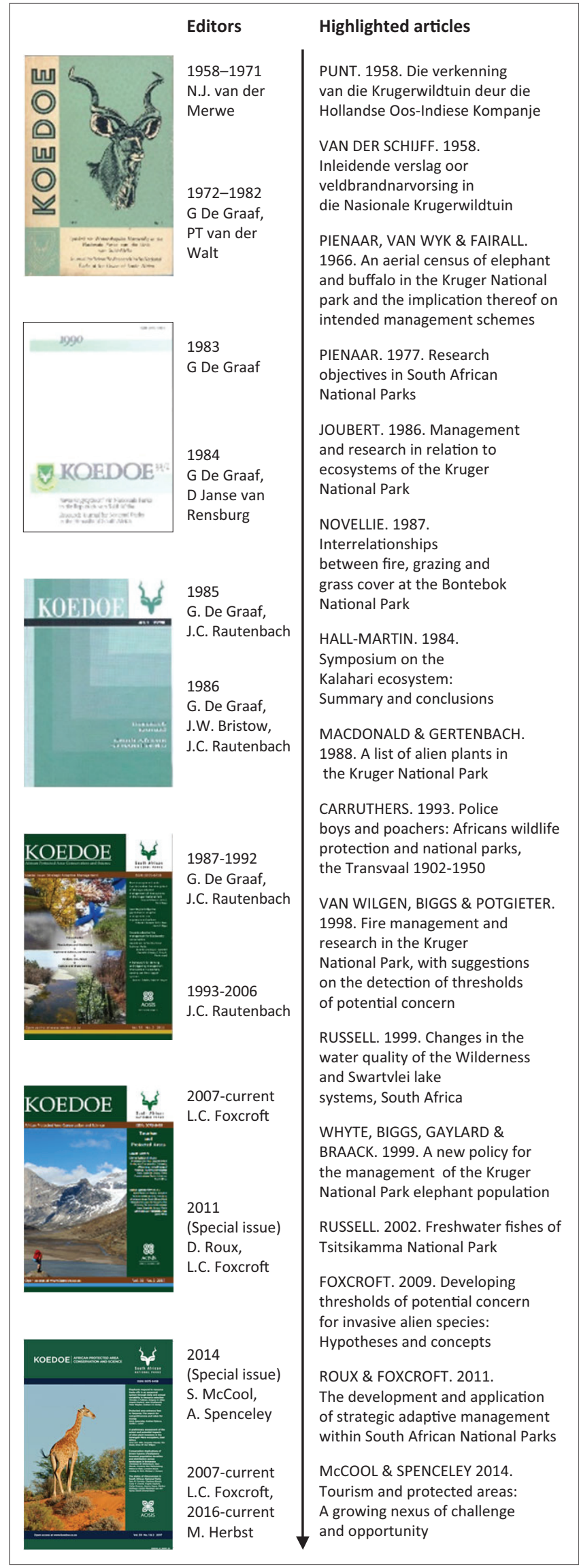

Source: L.C. Foxcroft and journal cover images from Koedoe archives

FIGURE 1: A sample of articles discussed in this article and journal editors from Koedoe's 60-year history.
In addition, we want to flag special issues of Koedoe, the contents of which examine a topic or national park in detail and that are certainly worth revisiting, even re-enacting. The earliest was in 1977, 'Proceedings of the symposium, "The state of nature conservation in southern Africa"', held to commemorate the 50th anniversary of the South African National Parks Act of 1926. The meeting was a large affair held in the KNP with about 200 delegates, of whom some 18 were black Africans, and there was one lone woman. Many parts of southern Africa had a presence, including Swaziland, Rhodesia, Lesotho and Botswana, as well as QwaQwa, Lebowa, 'Vendaland', 'Zululand', Ciskei and other 'selfgoverning' states in South Africa. The proceedings encompassed wilderness, education, private nature reserves, the status of nature conservation in various states and regions, tourism, marine parks, and botanical and zoological gardens. The 1977 symposium was path-breaking in including landscape planning as part of the general brief for protected areas, as was a call from the director of the newly established Department of Planning and the Environment, who urged national park authorities to work with all the other state departments so that nature conservation would become part of a coordinated national system of land-use planning.

Of the many contributions to the 1977 symposium, one of the few to deal explicitly with research was U. de V. (Tol) Pienaar's (1977) 'Research objectives in South African National Parks'. For this reason, and as Pienaar was one of the foremost scientists and managers of the NPB, becoming warden of the KPN and later chief director of the NPB, it has a place in our selection. Pienaar (1977) ventured that:

... the primary objectives of any research program in our national parks should therefore be a study of ecosystems and their interrelationships, with the objective of supplying the managerial basis for maintaining optimum conditions within the ecosystems, without endangering the interdependency of the components or the quality of the environment. (p. 39)

The occasion recorded in Koedoe 1977 served as a mirror of the southern African nature conservation community at that time, and perhaps an analogous meeting for our era should be put on the agenda, given the immensity of the environmental, scientific and political changes since the 1970s and the challenges that confront the conservation science community in the 21st century. (Pienaar, U.d.V., 1977, 'Research objectives in South African National Parks', in Proceedings of a symposium on the state of nature conservation in southern Africa, Kruger National Park, 1976, G. de Graaff \& P.T. van der Walt (eds.), supplement, Koedoe 20(2), 38-48. https:/ / doi.org/10.4102/koedoe.v20i2.1266)

A decade later, in 1986, another article in Koedoe also dealt with the wider principles of national park science. The author was Salomon Joubert, who was later to become warden of the KNP. In 'Management and research in relation to ecosystems of the Kruger National Park', Joubert (1986) maintained the KNP's commitment to preserving and perpetuating ecosystems. This was to be done because these 
'living organisms' (biodiversity only entered the lexicon of Koedoe in 1995) counteracted the depletion of natural resources and provided recreational facilities for 'modern day technological man'. Management options were to be guided by the 'minimum intervention' principle, although other than emphasising monitoring, precisely how and when such intervention might be scientifically determined was left unstated. (Joubert, S.C.J., 1986, 'Management and research in relation to ecosystems of the Kruger National Park', Koedoe 29, 157-163. https:/ / doi.org/10.4102/koedoe.v29i1.528)

The increasing complexity of national park science was aired in an important special issue in 2011. By then the time had arrived - somewhat haltingly - for an entirely new approach to science and management in South Africa's national parks. As the old guard left with changes to the country in 1994, and many staff and board retirements coincided, a new generation of scientists and managers proved ready to strike out in a new direction. That change was made especially noticeable through the adoption of strategic adaptive management (SAM), in place of the command and control paradigm that had been introduced in the 1960s. Terminology began to change from 'national parks' and 'ecosystems' to be replaced by 'protected areas' and 'complex social ecological systems'. The 2011 special issue of Koedoe gave considerable attention to dissecting SAM, and we reproduce here the introduction to the volume by Dirk Roux and Llewellyn Foxcroft (2011). (Roux, D.J. \& Foxcroft, L.C., 2011, 'The development and application of strategic adaptive management within South African National Parks', Koedoe 53(2), 5 pages. https://doi. org/10.4102/koedoe.v53i2.1049)

Two other Koedoe special issues are also worth noting. In 1983 a symposium was held in Pretoria on the Kalahari ecosystem, and the voluminous proceedings were published the following year. The profile of the KGNP has faded in recent years, but it was once extremely high in NPB research circles, and the idea of an ecosystem-wide research think tank is certainly a worthwhile project even now. The large 1983 meeting was a tribute to Dr F.C. (Fritz) Eloff, chairman of the NPB since 1979 and soon to retire as professor of Zoology at the University of Pretoria. Eloff had taken a close interest in the lions of the KGNP and became a consultant for the Cat Specialist Group as well as for the Survival Service Commission (later renamed the 'Species Survival Commission') of the IUCN. The contents of this special issue were wide-ranging and included articles on geology and soil; water resources and vegetation; fire; mammal, bird and invertebrate studies; as well as a list of relevant publications on the KGNP. As Anthony Hall-Martin (1984) pointed out in his conclusion, the symposium and the publication provided a welcome synthesis of the state of knowledge about the KGNP, while also identifying important gaps. (Hall-Martin, A.J., 1984, 'Symposium on the Kalahari ecosystem: Summary and conclusions', in 'Proceedings of a Symposium on the Kalahari Ecosystem 1983', eds G. de Graaff and D.J. van Rensburg, supplement, Koedoe, 327-333. https:/ / doi. org/10.4102/koedoe.v27i2.589)
The second special issue that opens a window into national park science is more recent - 2014. Edited by Stephen McCool and Anna Spenceley (2014), two members of the IUCN's Tourism and Protected Areas Specialist Group, World Commission on Protected Areas, this highlighted the importance of tourism, as a research science, to aid funding and capacity-building. It further emphasised the importance of national parks to local communities and local and international visitors. The introductory article, 'Tourism and protected areas: A growing nexus of challenge and opportunity', is reproduced here. One article in the issue is of particular importance to South Africa, and it is pleasing to see the wide range of international case studies that are presented. (McCool, S. and Spenceley, A., 2014, 'Tourism and protected areas: A growing nexus of challenge and opportunity', in McCool, S. \& Spenceley, A., eds, 'Tourism and protected areas: A growing nexus of challenge and opportunity', Koedoe 56(2), Art. \#1221, 2 pages. https:/ /dx. doi.org/10.4102/koedoe.v56i2.1221)

South African National Parks were once well known (and vilified) internationally for policies that manipulated the environment, provided water, fresh seasonal grazing thanks to a regulated fire regime and that aimed to keep large mammal populations at predetermined annual levels. Koedoe appeared in the era when drugs and darting of wildlife became possible, and this soon became both refined and routine, enabling selected wild animals to be translocated and thus saved from extinction, to repopulate areas where they once occurred and to be culled. Between 1960 and 1990, Koedoe published nearly 20 articles on marking and darting, explaining the drugs applicable to certain species and their advantages and disadvantages. In preparation for the culling programme, Pienaar, van Wyk and Fairall (1966) published 'An aerial census of elephant and buffalo in the Kruger National Park and the implication thereof on intended management schemes' in Koedoe. Ending elephant culling was controversial and difficult as the Koedoe article by Whyte et al. (1999) explains. (Pienaar, U. de V., Van Wyk, P. \& Fairall, N., 1966, 'An aerial census of elephant and buffalo in the Kruger National park and the implication thereof on intended management schemes', Koedoe 9, 40-107. https:// doi.org/10.4102/koedoe.v9i1.781, and Whyte, I.J., Biggs, H.C., Gaylard, A. \& Braack, L.E.O., 1999, 'A new policy for the management of the Kruger National Park elephant population', Koedoe 42(1), 111-32. https:/ / doi.org/10.4102/ koedoe.v42i1.228)

The small group of scientists employed in the NPB, together with outside experts, generally invited, were diligent in publishing their work in Koedoe. It is not surprising that for at least the first 30 years, most articles dealt with individual species, of which mammal species were the most numerous by far. Other taxa were not, however, totally neglected: invertebrates, birds and fishes were included by way of checklists, surveys and species descriptions. Given the international focus on endangered animals, this listing of species and, where possible, recording their abundance or scarcity coincided with the initial publication of the IUCN 
Red Data Lists that began in 1964. A creative research article that brought together the elements of an ecosystem in a national park was that by Peter Novellie (1987). It has been influential, often cited, and is important for its relevance to an endangered species that NPB struggled for decades to preserve. (Novellie, P., 1987, 'Interrelationships between fire, grazing and grass cover at the Bontebok National Park', Koedoe 30, 1-17. https: / / doi.org/10.4102/koedoe.v30i1.498)

Veld-burning (now called 'fire ecology') was given attention in the very first issue of Koedoe in 1958. In an extended article, Van der Schijff (1958) explained why regulated burning was necessary, using four veld types for his experiment. It is fascinating to compare his article with that 40 years later by van Wilgen, Biggs and Potgieter (1998). (Van der Schijff, H.P., 1958, 'Inleidende verslag oor veldbrandnarvorsing in die Nasionale Krugerwildtuin', Koedoe 1, 60-94. https://doi. org/10.4102/koedoe.v1i1.865 and Van Wilgen, B.W., Biggs H.C. \& Potgieter, A.L.F., 1998, 'Fire management and research in the Kruger National Park, with suggestions on the detection of thresholds of potential concern', Koedoe 41, 69-87. https:/ / doi.org/10.4102/koedoe.v41i1.248)

Invasion ecology (or invasion biology) is a science that has become a priority within SANParks since 1958. Despite managing for a 'pristine' ecosystem, alien flora quickly invaded the KNP and other national parks, and a list was published in Koedoe in 1988. At that time, there were 156 alien plant species recorded in the KNP, of which 113 were considered 'invasive'. The authors, Ian Macdonald and Willem Gertenbach (Macdonald and Gertenbach 1988), warned that a coordinated regional campaign to control them would be required. The invasion of alien biota, however, seems unstoppable and it is salutary to compare the 1988 article with that by Foxcroft(2009) in Koedoe. (Macdonald, I.A.W. \& Gertenbach, W.P.D., 1988, 'A list of alien plants in the Kruger National Park', Koedoe 31, 137-150. https:/ / doi.org/10.4102/ koedoe.v31i1.491, and Foxcroft, L.C., 2009, 'Developing thresholds of potential concern for invasive alien species: Hypotheses and concepts", Koedoe 51(1), Art. \#157, 6 pages. https:/ /doi.org/10.4102/koedoe.v51i1.157)

The expansion of the national park system under SANParks over the past two decades has provided opportunities for a wider variety of scientific research for inclusion in Koedoe, although some of the newer parks have yet to find a research advocate and provide more than checklists of biota. The KNP continues to dominate Koedoe and indeed the research agenda of SANParks. However, as the Garden Route National Park took shape - including the lake systems - the protection and study of these water bodies became critically important. Ian Russell's (1999) article entitled 'Changes in the water quality of the Wilderness and Swartvlei lake systems, South Africa' is well worth reading, as is his (2002) article entitled 'Freshwater fishes of Tsitsikamma National Park'. (Russell, I.A., 2002, 'Freshwater fishes of Tsitsikamma National Park', Koedoe 45(2), 13-17. https://doi.org/10.4102/koedoe. v45i2.34, and Russell, I.A., 1999, 'Changes in the water quality of the Wilderness and Swartvlei lake systems, South Africa',
Koedoe 42(1), 57-72. https://doi.org/10.4102/koedoe. $\mathrm{v} 42 \mathrm{i} 1.222)$

The very first article in the 1958 line-up in Koedoe was by Willem H.J. Punt (1958), a local antiquarian with a flair for colonialist micro-history, particularly the minutiae of how explorers opened up the southern African interior to 'white civilisation'. The object of Punt's attention was a group from the Netherlands that briefly penetrated the Lowveld from Lourenço Marques (Maputo) in Mozambique, thereby, in his view, initiating a European presence of long standing in the vicinity of the KNP. Naturally, this kind of historical research that valorised white conservation efforts chimed with the socio-political era of apartheid in the 1950s. Not until the 1990s was another historical perspective introduced to Koedoe with Jane Carruthers's (1993) article on the contributory role of Africans in national park developments. Regrettably, the number of papers in Koedoe on historical and archaeological topics relating to SANParks has diminished over the years, although these are critically important scientific disciplines in protected areas and humanise the landscape. (Punt, W.H.J., 1958, ‘Die verkenning van die Krugerwildtuin deur die Hollandse Oos-Indiese Kompanje, 1725', Koedoe 1, 1-18. https://doi.org/10.4102/koedoe.v1i1.863, and Carruthers, J., 1993, "Police boys" and poachers: Africans wildlife protection and national parks, the Transvaal 1902-1950', Koedoe 36(2), 11-22. https://doi.org/10.4102/ koedoe.v36i2.371)

\section{Conclusion}

While a large portion of articles published in Koedoe have, understandably, emanated from Kruger, here we have included the Kalahari Gemsbok, Bontebok and Tsitsikamma (now Garden Route) National Parks to provide other perspectives. The Kalahari Gemsbok had a multifaceted and productive research programme, while work at Bontebok illustrates early grappling with an ecosystems approach fire, grazing and grass interactions. The special issues of Koedoe were influential in that they brought together a wide range of thinking and research on specific and very relevant topics, thus providing accessible information that might, more often, only be found in a book. The 1977 symposium on the state of conservation resulted in a large workshop of practitioners who debated the merits and flaws of the science at the time and suggested possibilities for the future. Over the years, tourism has been the financial bedrock of national parks and the science around that discipline is an expanding and important field. Of equal importance is the need for humanity to interact with nature in an era when urbanisation is burgeoning, and this is provided by visitor access. The special issue on adaptive management is vitally important because it has been promoted in recent years as a favourable method of managing adaptive, complex social-ecological systems. SANParks has been hailed as a forerunner in the continued development and implementation of adaptive management and articles from the special issue have been downloaded 225 000 times (as of March 2018). 
We hope that the articles we have highlighted will inspire readers to consult the older issues of the journal and that charting the changing contours of national park science will be informative and instructive, as well as illuminate how fresh and complex ecological fields, such as fire ecology and invasion biology, have emerged as large areas of research. No doubt, the learning process will continue.

The ease of open access through the Koedoe website, and the publication of a number of indexes and statistical material, will make further search easy and rewarding. Change is a certainty, and we can be sure that the scientific record of today that is considered to be unassailable will also alter with time.

\section{Acknowledgements}

The authors thank the editor and anonymous reviewers for their comments.

\section{Competing interests}

The authors declare that they have no financial or personal relationships that may have inappropriately influenced them in writing this article.

\section{Authors' contributions}

J.C. identified the articles reviewed and wrote the first draft of the manuscript. L.C.F. collaborated on identifying the articles reviewed and wrote the manuscript.

\section{Funding information}

Koedoe is supported by South African National Parks.

\section{References}

Carruthers, J., 1993, "Police boys" and poachers: Africans wildlife protection and national parks, the Transvaal 1902-1950', Koedoe 36(2), 11-22. https://doi. org/10.4102/koedoe.v36i2.371

Carruthers, J., 2017, National Park Science: A century of research in South Africa, Cambridge University Press, Cambridge, United Kingdom.
Foxcroft, L.C. \& Herbst, M., 2017, 'Status and trends in the global growth of Koedoe between 1958 and 2016', Koedoe 59(1), 5 pages. https://doi.org/10.4102/koedoe. v59i1.1500

Foxcroft, L.C., 2008, 'Fifty years of Koedoe: Current status and future directions', Koedoe 50(1), Art. \#124, 2 pages. https://doi.org/10.4102/koedoe.v50i1.124

Foxcroft, L.C., 2009, 'Developing thresholds of potential concern for invasive alien species: Hypotheses and concepts", Koedoe 51(1), Art. \#157, 6 pages. https://doi. org/10.4102/koedoe.v51i1.157

Hall-Martin, A.J., 1984, 'Symposium on the Kalahari ecosystem: Summary and conclusions', in Proceedings of a symposium on the Kalahari ecosystem 1983, G. de Graaff \& D.J. van Rensburg (eds.), supplement, Koedoe 27(2), 327-333. https://doi.org/10.4102/koedoe.v27i2.589

IUCN (International Union for the Conservation of Nature and Natural Resources), 1960, Proceedings of the 6th General Assembly, Athens, 11-19 September 1958 (Brussels, IUCN, 1960), viewed 30 January 2019, from https://portals.iucn.org/ library/efiles/documents/GA-6th-005.pdf.

IUPN (International Union for the Protection of Nature), 1948, International Union for the Protection of Nature Established at Fountainebleau, 05 October 1948, viewed 30 January 2019, from https://portals.iucn.org/library/efiles/documents/194830 January
$001 . p d f$

Joubert, S.C.J., 1986, 'Management and research in relation to ecosystems of the Kruger National Park', Koedoe 29, 157-163. https://doi.org/10.4102/koedoe. v29i1.528

Macdonald, I.A.W. \& Gertenbach, W.P.D., 1988, 'A list of alien plants in the Kruger National Park', Koedoe 31, 137-150. https://doi.org/10.4102/koedoe.v31i1.491

McCool, S. \& Spenceley, A., 2014, 'Tourism and protected areas: A growing nexus of challenge and opportunity', in S. McCool \& A. Spenceley (eds.), Tourism and protected areas: A growing nexus of challenge and opportunity, Koedoe 56(2), Art. \#1221, 2 pages. https://doi.org/10.4102/koedoe.v56i2.1221

Novellie, P., 1987, 'Interrelationships between fire, grazing and grass cover at the Bontebok National Park', Koedoe 30, 1-17. https://doi.org/10.4102/koedoe. v30i1.498

Pienaar, U.d.V., 1977, 'Research objectives in South African National Parks', in Proceedings of a symposium on the state of nature conservation in southern Africa, Kruger National Park, 1976, G. de Graaff \& P.T. van der Walt (eds.), supplement, Koedoe 20(2), 38-48. https://doi.org/10.4102/koedoe.v20i2.1266

Pienaar, U.d.V., Van Wyk, P. \& Fairall, N., 1966, 'An aerial census of elephant and buffalo in the Kruger National park and the implication thereof on intended management schemes', Koedoe 9, 40-107. https://doi.org/10.4102/koedoe.v9i1.781

Punt, W.H.J., 1958, 'Die verkenning van die Krugerwildtuin deur die Hollandse OosIndiese Kompanje, 1725', Koedoe 1, 1-18. https://doi.org/10.4102/koedoe.v1i1.863

Roux, D.J. \& Foxcroft, L.C., 2011, 'The development and application of strategic adaptive management within South African National Parks', Koedoe 53(2), 5 pages. https://doi.org/10.4102/koedoe.v53i2.1049

Russell, I.A., 2002, 'Freshwater fishes of Tsitsikamma National Park', Koedoe 45(2), 13-17. https://doi.org/10.4102/koedoe.v45i2.34

Russell, I.A., 1999, 'Changes in the water quality of the Wilderness and Swartvlei lake systems, South Africa', Koedoe 42(1), 57-72. https://doi.org/10.4102/koedoe. v42i1.222

Van der Schijff, H.P., 1958, 'Inleidende verslag oor veldbrandnarvorsing in die Nasionale Krugerwildtuin', Koedoe 1, 60-94. https://doi.org/10.4102/koedoe. v1i1.865

Van Wilgen, B.W., Biggs, H.C. \& Potgieter, A.L.F., 1998, 'Fire management and research in the Kruger National Park, with suggestions on the detection of thresholds of potential concern', Koedoe 41, 69-87. https://doi.org/10.4102/koedoe.v41i1.248

Whyte, I.J., Biggs, H.C., Gaylard, A. \& Braack, L.E.O., 1999, 'A new policy for the management of the Kruger National Park elephant population', Koedoe 42(1), 111-32. https://doi.org/10.4102/koedoe.v42i1.228 